\title{
Manufacturing of phosphoric acid from hydroxyapatite, contained in the ashes of the incinerated meat-bone wastes
}

\author{
Kinga Krupa-Żuczek, Zygmunt Kowalski, Zbigniew Wzorek \\ Cracow University of Technology; Institute of Chemistry and Inorganic Technology, ul. Warszawska 24, 31-155 Kraków, \\ Poland, e-mail: kingak@indy.chemia.pk.edu.pl
}

\begin{abstract}
The results of the investigations concerning phosphoric acid manufacturing, by the extraction method, from the ashes containing hydroxyapatite, obtained through the thermal treatment of bone sludge have been presented. The incinerated bone sludge with $\sim 16 \% \mathrm{P}$ content and the minimal amount of impurities can be an alternative source for phosphoric acid production. The process consists in two stages. In the $1^{\text {st }}$ stage, reaction of hydroxyapatite with phosphoric acid resulting in monocalcium phosphate formation in the solution obtained is carried out. The tests revealed that overall hydroxyapatite dissolution in phosphoric acid takes place when the concentration is $37 \% \mathrm{H}_{3} \mathrm{PO}_{4}$. In the $2^{\text {nd }}$ stage monocalcium phosphate is converted into calcium sulphate using concentrated sulphuric acid at the recommended temperature of $95^{\circ} \mathrm{C}$. The principles of the technological idea of the process of phosphoric acid manufacturing from HA-containing ashes, obtained by bone wastes incineration, as well as a preliminary economic analysis for the production of $10000 \mathrm{t} / \mathrm{year}$ of food-grade phosphoric acid have been developed.
\end{abstract}

Keywords: meat waste, hydroxyapatite, phosphoric acid.

\section{INTRODUCTION}

About $18 \mathrm{mln} \mathrm{t} / \mathrm{year}$ of meat wastes, containing phosphorus compound, are generated by the meat industry in the European Union countries. That sort of waste can be an alternative source of phosphorus, while the amount of natural phosphate rock is in continuous depletion ${ }^{1-5}$. According to the ,cleaner technology" rules, more considerations has been given to the substitution of natural raw materials for wastes and for preventing the waste release in the environment $^{1,2}$.

Practical processing of meat industry wastes is regulated by the European Union law ${ }^{5,6}$. According to the law, the wastes are divided into categories depending on the risk of infectious disease. The wastes such as meat-bone crushes and all kind of animal parts that may generate potential risk of CJD disease belong to the $1^{\text {st }}$ category of high risk ${ }^{5,6}$.

The only possible method, enabling neutralisation of these wastes, is thermal treatment at temperatures higher than $850^{\circ} \mathrm{C}$. The wastes of the $2^{\text {nd }}$ category are by-products derived from animals (droppings, enteron content), sludge from slaughterhouse sewage utilisation, and animal products containing veterinarian medicines. The wastes of this category have to be utilised in incinerating plants, too. Bone sludge (protein-free and fat-free bones) - skin, hoofs, horns, pigs bristle, feathers, blood recovered from other than ruminant animals, parts of the animals suitable for consumption, and those, though discarded by the people, estimated as no causing danger of a disease transfer from animal to human being belong to the $3^{\text {rd }}$ category of wastes. They can be utilised thermally or processed into biogas or compost.

In the paper, the results concerning the extraction of phosphoric acid from the ashes obtained by thermal processing of bone sludge have been presented.

\section{EXPERIMENTAL PART}

Bone tissue, beside the meat tissue, is the main constituent of the wastes generated by slaughterhouses ${ }^{5,7}$. The bones, after initial preparation, removing metallic pieces, and crushing, are subjected to hydrolysis ${ }^{\mathbf{8}, \boldsymbol{9}}$, yielding ,protein hydro- lysate" and bone sludge. Chemical composition of sludge, obtained from different sorts of bone, does not differ much (Table 1$)^{5}$.

Table 1. Chemical composition of bone sludge

\begin{tabular}{|l|c|c|c|c|c|}
\hline \multirow{2}{*}{$\begin{array}{l}\text { Sludge of bone as } \\
\text { below }\end{array}$} & \multicolumn{5}{|c|}{ Content [mass \%] } \\
\cline { 2 - 6 } & $\mathrm{H}_{2} \mathrm{O}$ & $\mathrm{P}$ & $\mathrm{Ca}$ & Fat & Proteins \\
\hline $\mathrm{Ox}$ & 7.07 & 14.12 & 25.8 & 2.37 & 20.38 \\
\hline $\mathrm{Pig}$ & 6.53 & 14.09 & 22.8 & 3.13 & 24.04 \\
\hline Pig legs & 7.06 & 13.98 & 20.6 & 2.89 & 18.69 \\
\hline
\end{tabular}

The phosphorus content $(\sim 14 \%)$ is at the level of that in phosphate rocks. The tested bone sludge (a mixture $1: 1: 1$ by weight), composed of pig legs, pig bones and ox bones contained pieces from a few to dozens $\mathrm{cm}$ in large. The composition (wt.\%) of the sludge was: $\mathrm{H}_{2} \mathrm{O} \sim 7.0$; organic matter $\sim 16.1$ (in wet mass), $\sim 17.3$ (in dry); fat $=3.0$; protein $=14.3$; phosphorus $\mathrm{P} \sim 13.1$ (in wet mass), $\sim 14.1$ (in dry); $\mathrm{CaO} \sim 35.7$ (in wet mass), 38.4 (in dry) 5 . The combustion energy determined using the calorimeter KL-12Mn (Precyzja-Bit Company) was $7.9 \mathrm{MJ} / \mathrm{kg}$ (in comparison, the heat of coal combustion is $20.66 \mathrm{MJ} / \mathrm{kg})^{5,11}$.

The X-ray diffraction analysis (XRD) of the sludge was performed with the Philips X'Pert diffractometer equipped with the graphite monochromator PW 1752/00 and anode copper. The result obtained revealed that hydroxyapatite, (HA), was the only crystalline phase in bone sludge (Figure 1). The thermogravimetric analysis in air, (TGA), using the simultaneously recorded DTA-DTG system SDT 2960 TA Instruments, presented in Figure 2, demonstrates three steps of bone sludge decomposition, while the temperature is increasing. The combustion of the organic matter is performed up to $\sim 600^{\circ} \mathrm{C}$. The fourth endothermic effect around $800^{\circ} \mathrm{C}$ is likely to be associated with $\mathrm{CaCO}_{3}$ decomposition.

The bone sludge was incinerated in a stationary chamber oven at 600 and $950^{\circ} \mathrm{C}$ for 3 hours in air atmosphere, ${ }^{5,12}$. Phosphorus and calcium concentration, in the ashes obtained, were analysed according to standards ${ }^{10,13}$. The chemical composition of the ashes is summarised in Table 2. The XRD patterns of the ashes, presented in Figure 4, indicate that hydroxyapatite is the only crystalline phase in the ashes. 


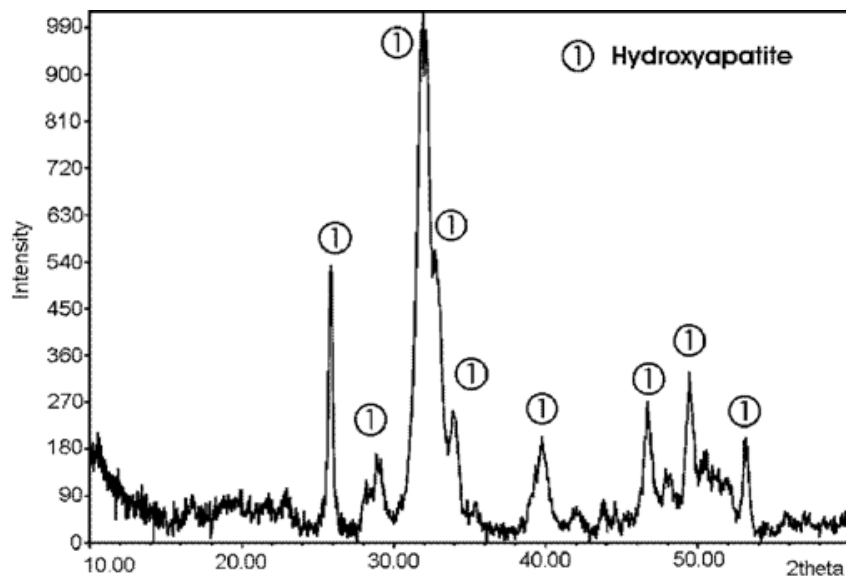

Figure 1. X-ray diffraction pattern, (XRD), of bone sludge

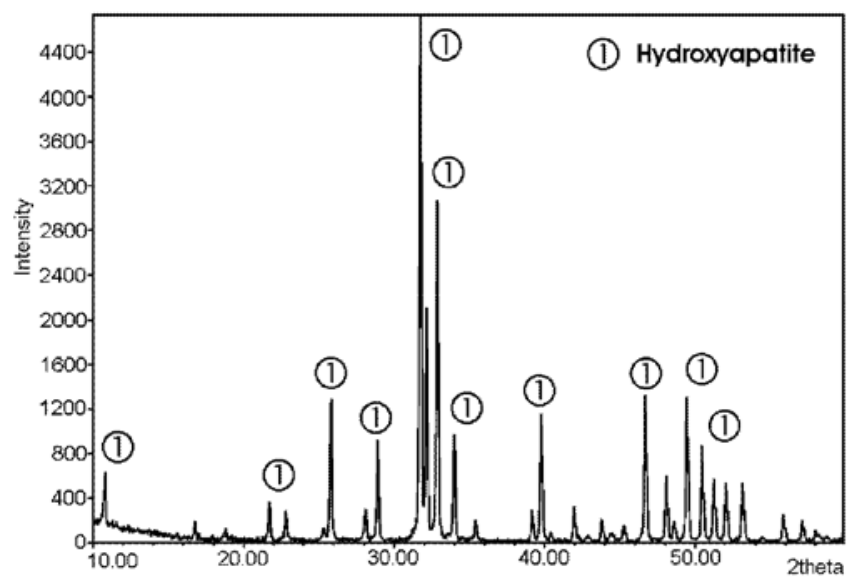

Figure 3. XRD of the ash obtained through bone sludge incineration in the stationary chamber oven at $950^{\circ} \mathrm{C}$

Sample: Szlam kostny Size: $7.0750 \mathrm{mg}$

TGA-DTA

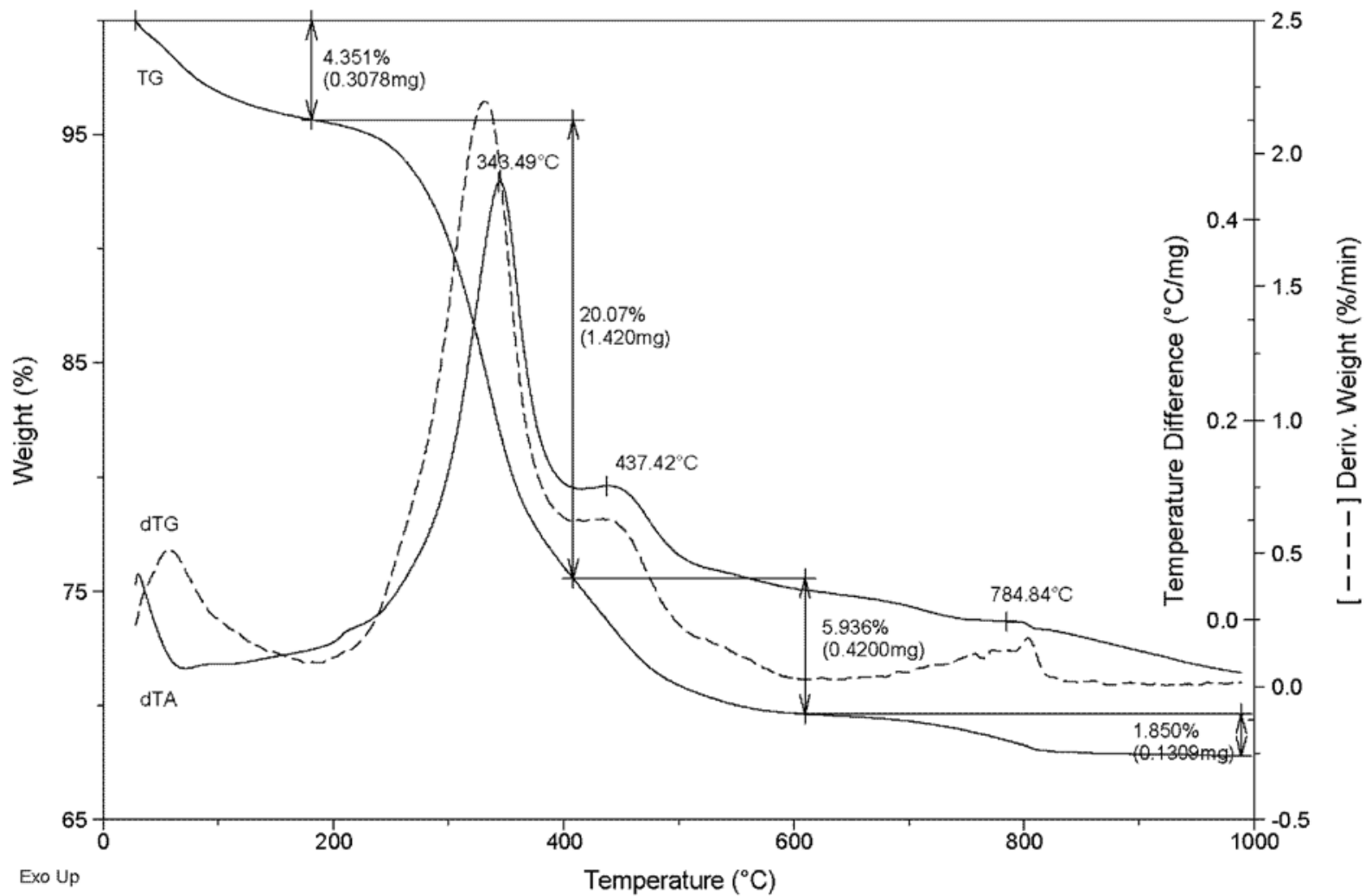

Figure 2. DTA-DTG curves of bone sludge TGA analysis in the air

The morphology of the ashes obtained was investigated by the scanning electron microscopy method (SEM), using the S-4700 Hitachi, equipped with the EDS analyzer ${ }^{5}$. It has been found (Figure 4 ) that the ash resulted from bone sludge incineration at the temperature of $950^{\circ} \mathrm{C}$ in the stationary chamber oven in air atmosphere is of homogeneous structure. The oval-shaped grains of the crystallites of about 0.5 $-1.0 \mu \mathrm{m}$ large can be seen in the picture. The absence of agglomerates indicates the lack of agglutination. The white shades, shown in the picture, may indicate the melted areas of the sample resulted from overheating. That may indicate that the incineration temperature was too high.

The tests on incineration indicated that the ash obtained was almost pure hydroxyapatite. The homogenous chemical composition and the chemical properties, especially its pu-
Table 2. Chemical composition of the ashes obtained by incineration of bone sludge in the stationary chamber oven at temperatures of $600^{\circ} \mathrm{C}$ and $950^{\circ} \mathrm{C}^{5}$

\begin{tabular}{|c|c|c|c|}
\hline $\begin{array}{c}\text { Temperature } \\
\text { of } \\
\text { incineration }\end{array}$ & $\begin{array}{c}\text { Weight } \\
\text { loss } \\
{[\%]}\end{array}$ & $\begin{array}{c}\text { Phosphorus } \\
\text { content } \\
\text { [mass \%] }\end{array}$ & $\begin{array}{c}\text { Calcium } \\
\text { content } \\
\text { [mass \%] }\end{array}$ \\
\hline $600^{\circ} \mathrm{C}$ & 34 & 15.8 & 39.1 \\
\hline $950^{\circ} \mathrm{C}$ & 35 & 16.4 & 39.2 \\
\hline
\end{tabular}

rity and lack of heavy metals, facilitates its processing when it is used as a source of phosphorus ${ }^{5,12}$. The incinerated bone sludge can be used for food-grade phosphoric acid production. 


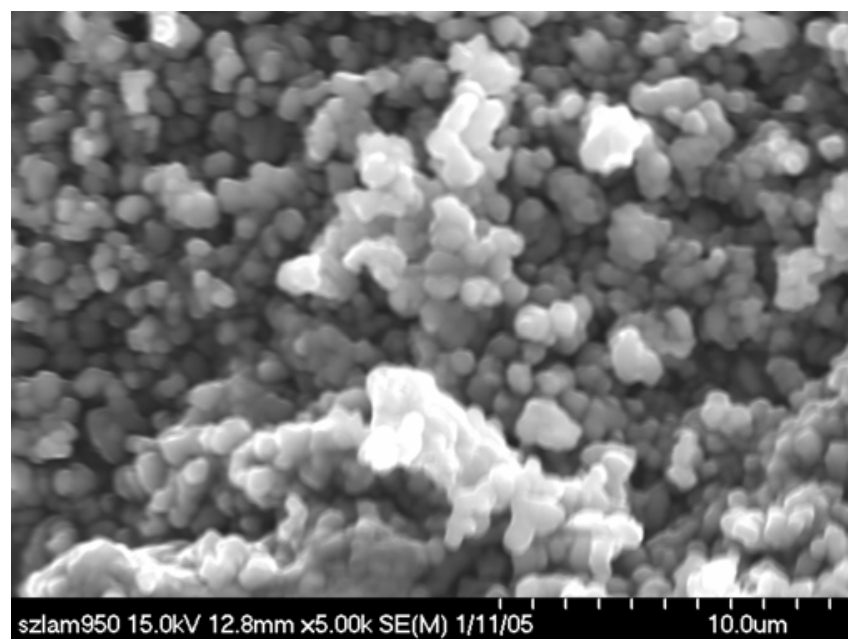

Figure 4. Microphotograph of the surface of the ash, obtained by bone sludge incineration at $950^{\circ} \mathrm{C}$ in the air

\section{PHOSPHORIC ACID MANUFACTURING}

Phosphoric acid was obtained by the extraction of $\mathrm{H}_{3} \mathrm{PO}_{4}$ from hydroxyapatite with the concentrated sulphuric acid ${ }^{\mathbf{1 4}-16}$.

$2 \mathrm{Ca}_{5}\left(\mathrm{PO}_{4}\right)_{3} \mathrm{OH}+10 \mathrm{H}_{2} \mathrm{SO}_{4}+18 \mathrm{H}_{2} \mathrm{O}=$

$6 \mathrm{H}_{3} \mathrm{PO}_{4}+10 \mathrm{CaSO}_{4} \cdot 2 \mathrm{H}_{2} \mathrm{O}$

The process was carried out in two stages. In the $1^{\text {st }}$ stage hydroxyapatite was treated with phosphoric acid to obtain a solution of monocalcium phosphate $\mathrm{Ca}\left(\mathrm{H}_{2} \mathrm{PO}_{4}\right)_{2}$. In the $2^{\text {nd }}$ stage calcium sulphate was precipitated using sulphuric acid ${ }^{5,16}$. The goal the first part of the investigations was to determine the amount of phosphoric acid sufficient for the total dissolution of the hydroxyapatite at $75^{\circ} \mathrm{C}$. The reaction was carried out for $4 \mathrm{~h}$ in a glass reactor equipped with the heating jacket, reflux condenser, and a mechanical stirrer ${ }^{5}$. The results are shown in Table 3.

Table 3 demonstrates that the lowest phosphoric acid concentration sufficient for the total dissolution of $\mathrm{Ca}_{5}\left(\mathrm{PO}_{4}\right)_{3} \mathrm{OH}$ is $27.5 \% \mathrm{H}_{3} \mathrm{PO}_{4}$, and that does not depend on the ratio of $\mathrm{Ca}_{5}\left(\mathrm{PO}_{4}\right)_{3} \mathrm{OH} / \mathrm{H}_{3} \mathrm{PO}_{4}$. However, while the

Table 3. Results on hydroxyapatite dissolution in phosphoric acid of different $\mathrm{H}_{3} \mathrm{PO}_{4}$ concentration

\begin{tabular}{|c|c|c|c|c|c|}
\hline $\begin{array}{c}\mathrm{H}_{3} \mathrm{PO}_{4} \\
{[\%]}\end{array}$ & $\begin{array}{c}\text { Weight ratio } \\
\mathrm{Ca}_{5}\left(\mathrm{PO}_{4}\right)_{3} \mathrm{OH} / \\
\mathrm{H}_{3} \mathrm{PO}_{4}\end{array}$ & Dissolution & $\begin{array}{c}\text { Acid conc. after } \\
\text { dissolution } \\
{\left[\% \mathrm{H}_{3} \mathrm{PO}_{4}\right]}\end{array}$ & Phase composition of the solid & $\begin{array}{l}\text { Soluble in water } \mathrm{P} \\
\text { remained in the solid } \\
\text { after dissolution } \\
{\left[\% \mathrm{H}_{3} \mathrm{PO}_{4}\right]}\end{array}$ \\
\hline 10 & $1: 15$ & $\begin{array}{l}\text { Not total } \\
\text { dissolved }\end{array}$ & 13.5 & $\mathrm{Ca}_{5}\left(\mathrm{PO}_{4}\right)_{3} \mathrm{OH}$ & 4.3 \\
\hline 10 & $1: 14$ & $\begin{array}{c}\text { Not total } \\
\text { dissolved }\end{array}$ & 13.3 & $\mathrm{Ca}_{5}\left(\mathrm{PO}_{4}\right)_{3} \mathrm{OH}$ & 4.2 \\
\hline 10 & $1: 13$ & $\begin{array}{l}\text { Not total } \\
\text { dissolved }\end{array}$ & 13.7 & $\mathrm{Ca}_{5}\left(\mathrm{PO}_{4}\right)_{3} \mathrm{OH}$ & 4.0 \\
\hline 10 & $1: 12$ & $\begin{array}{l}\text { Not total } \\
\text { dissolved }\end{array}$ & 13.7 & $\mathrm{Ca}_{5}\left(\mathrm{PO}_{4}\right)_{3} \mathrm{OH}$ & 4.0 \\
\hline 10 & $1: 11$ & $\begin{array}{l}\text { Not total } \\
\text { dissolved }\end{array}$ & 13.6 & $\mathrm{Ca}_{5}\left(\mathrm{PO}_{4}\right)_{3} \mathrm{OH}$ & 3.9 \\
\hline 20 & $1: 15$ & $\begin{array}{l}\text { Not total } \\
\text { dissolved }\end{array}$ & 24.1 & $\mathrm{Ca}_{5}\left(\mathrm{PO}_{4}\right)_{3} \mathrm{OH}$ & 4.0 \\
\hline 20 & $1: 14$ & $\begin{array}{l}\text { Not total } \\
\text { dissolved }\end{array}$ & 24.1 & $\mathrm{Ca}_{5}\left(\mathrm{PO}_{4}\right)_{3} \mathrm{OH}$ & 4.0 \\
\hline 20 & $1: 13$ & $\begin{array}{l}\text { Not total } \\
\text { dissolved }\end{array}$ & 24.6 & $\mathrm{Ca}_{5}\left(\mathrm{PO}_{4}\right)_{3} \mathrm{OH}$ & 4.1 \\
\hline 20 & $1: 12$ & $\begin{array}{l}\text { Not total } \\
\text { dissolved }\end{array}$ & 25.0 & $\mathrm{Ca}_{5}\left(\mathrm{PO}_{4}\right)_{3} \mathrm{OH}$ & 3.9 \\
\hline 20 & $1: 11$ & $\begin{array}{l}\text { Not total } \\
\text { dissolved }\end{array}$ & 22.5 & $\mathrm{Ca}_{5}\left(\mathrm{PO}_{4}\right)_{3} \mathrm{OH}$ & 3.8 \\
\hline 30 & $1: 15$ & Dissolved & 35.6 & No solid & 0 \\
\hline 30 & $1: 14$ & Dissolved & 35.5 & No solid & 0 \\
\hline 30 & $1: 13$ & Dissolved & 35.0 & No solid & 0 \\
\hline 30 & $1: 12$ & Dissolved & 35.0 & No solid & 0 \\
\hline 30 & $1: 11$ & Dissolved & 35.1 & No solid & 0 \\
\hline 25 & $1: 15$ & $\begin{array}{l}\text { Not total } \\
\text { dissolved }\end{array}$ & 28.6 & $\begin{array}{c}\mathrm{Ca}_{5}\left(\mathrm{PO}_{4}\right)_{3} \mathrm{OH}, \\
\mathrm{CaPO}_{3}(\mathrm{OH}) \cdot 2 \mathrm{H}_{2} \mathrm{O}\end{array}$ & 3.7 \\
\hline 25 & $1: 14$ & $\begin{array}{r}\text { Not total } \\
\text { dissolved }\end{array}$ & 28.9 & $\begin{array}{c}\mathrm{Ca}_{5}\left(\mathrm{PO}_{4}\right)_{3} \mathrm{OH} \\
\mathrm{CaPO}_{3}(\mathrm{OH}) \cdot 2 \mathrm{H}_{2} \mathrm{O}\end{array}$ & 3.9 \\
\hline 25 & $1: 13$ & $\begin{array}{l}\text { Not total } \\
\text { dissolved }\end{array}$ & 29.0 & $\begin{array}{c}\mathrm{Ca}_{5}\left(\mathrm{PO}_{4}\right)_{3} \mathrm{OH} \\
\mathrm{CaPO}_{3}(\mathrm{OH}) \cdot 2 \mathrm{H}_{2} \mathrm{O}\end{array}$ & 4.0 \\
\hline 25 & $1: 12$ & $\begin{array}{l}\text { Not total } \\
\text { dissolved }\end{array}$ & 29.0 & $\begin{array}{c}\mathrm{Ca}_{5}\left(\mathrm{PO}_{4}\right)_{3} \mathrm{OH} \\
\mathrm{CaPO}_{3}(\mathrm{OH}) \cdot 2 \mathrm{H}_{2} \mathrm{O}\end{array}$ & 4.0 \\
\hline 25 & $1: 11$ & $\begin{array}{r}\text { Not total } \\
\text { dissolved }\end{array}$ & 28.6 & $\begin{array}{c}\mathrm{Ca}_{5}\left(\mathrm{PO}_{4}\right)_{3} \mathrm{OH} \\
\mathrm{CaPO}_{3}(\mathrm{OH}) \cdot 2 \mathrm{H}_{2} \mathrm{O}\end{array}$ & 3.9 \\
\hline 27,5 & $1: 15$ & Dissolved & 32.0 & No solid & 0 \\
\hline 27,5 & $1: 14$ & Dissolved & 32.5 & No solid & 0 \\
\hline 27,5 & $1: 13$ & Dissolved & 33.0 & No solid & 0 \\
\hline 27,5 & $1: 12$ & Dissolved & 32.0 & No solid & 0 \\
\hline 27,5 & $1: 11$ & Dissolved & 32.0 & No solid & 0 \\
\hline
\end{tabular}


clear solution obtained was left to stay, after a few hours secondary hydroxyapatite started to precipitate. A similar effect was observed when phosphoric acid, containing $30 \%$ $\mathrm{H}_{3} \mathrm{PO}_{4}$, was used. Further dissolution was carried out for 2 and $4 \mathrm{~h}$ at $75^{\circ} \mathrm{C}$, while the weight ratio of the solid/liquid was $1 / 15,1 / 11$ and the concentration of the acid was $10 ; 20 ; 25$; 27.5; and $30 \% \mathrm{H}_{3} \mathrm{PO}_{4}$ (Table 4). In the case of the 2-hour reaction with $10 \% \mathrm{H}_{3} \mathrm{PO}_{4}$, the dissolution of $\mathrm{Ca}_{5}\left(\mathrm{PO}_{4}\right)_{3} \mathrm{OH}$ was not completed. Also, the concentration of 20 and $25 \%$ $\mathrm{H}_{3} \mathrm{PO}_{4}$ was not sufficient for the total hydroxyapatite dissolution, additionally, the system reached some rate of oversaturation and a secondary precipitate of $\mathrm{CaHPO}_{4} \cdot 2 \mathrm{H}_{2} \mathrm{O}$ was formed ${ }^{5}$. Total hydroxyapatite dissolution was achieved in the acid of $27.5 \% \mathrm{H}_{3} \mathrm{PO}_{4}$ within 17 minutes.

Table 4 demonstrates that time is not significant for the hydroxyapatite dissolution under the investigated conditions.

To evaluate the optimal parameters (concentration, temperature, weight ratio of liquid/solid phases) of hydroxyapa-

Table 4. The rate of hydroxyapatite dissolution in phosphoric acid obtained for the lowest $(1: 11)$ and highest $(1: 15)$ ratio of the solid/liquid phase. Dissolution time 2 hours

\begin{tabular}{|c|c|c|c|c|}
\hline \multirow{2}{*}{$\begin{array}{c}\text { Concentration } \\
\mathrm{H}_{3} \mathrm{PO}_{4}[\%]\end{array}$} & \multicolumn{2}{|c|}{$\begin{array}{c}1: 15 \text { ratio of the } \\
\text { solid/liquid phase }\end{array}$} & \multicolumn{2}{c|}{$\begin{array}{c}1: 11 \text { ratio of the } \\
\text { solid/liquid phase }\end{array}$} \\
\cline { 2 - 5 } & \multicolumn{2}{|c|}{$\begin{array}{c}\text { Rate of } \mathrm{HA} \\
\text { dissolution } \%\end{array}$} & \multicolumn{2}{|c|}{$\begin{array}{c}\text { Rate of } \mathrm{HA} \\
\text { dissolution }\end{array}$} \\
\cline { 2 - 5 } & $2 \mathrm{~h}$ & $4 \mathrm{~h}$ & $2 \mathrm{~h}$ & $4 \mathrm{~h}$ \\
\hline 10 & 21.5 & 23.2 & 18.7 & 19.3 \\
\hline 20 & 88.3 & 88.6 & 40.3 & 41.9 \\
\hline 25 & 98.6 & 99.5 & 60.8 & 65.7 \\
\hline 27,5 & 100.0 & 100.0 & 100.0 & 100.0 \\
\hline 30 & 100.0 & 100.0 & 100.0 & 100.0 \\
\hline
\end{tabular}

tite dissolution in phosphoric acid a set of experiments was carried out according to the second order rotatable design in three factors $Z_{1}, Z_{2}, Z_{3}$ (Tables 5 and 6). The choice of the limiting concentrations of $\mathrm{H}_{3} \mathrm{PO}_{4}$ for the experiment was based on phase diagram of $\mathrm{H}_{2} \mathrm{O}-\mathrm{P}_{2} \mathrm{O}_{5}-\mathrm{CaO}{ }^{14}$, so that calcium sulphate was hydrated to the solid phase of the final product.

The tests on hydroxyapatite dissolution in phosphoric acid at different concentrations revealed that overall dissolution, without secondary precipitation, takes place only when the acid concentration was $37 \% \mathrm{H}_{3} \mathrm{PO}_{4}$. In the acid of $24 \%$ $\mathrm{H}_{3} \mathrm{PO}_{4}$ the hydroxyapatite was dissolving incongruently. In the acid of 50 and $59 \%$ of $\mathrm{H}_{3} \mathrm{PO}_{4}$ the secondary precipitate was formed.

The aim of the second stage of the experiments was to determine the most preferable for calcium sulphate precipitation conditions. In the experiment, the concentration of phosphoric acid, $\left(37 \% \mathrm{H}_{3} \mathrm{PO}_{4}\right)$ was maintained constant, while the temperature and sulphuric acid concentrations were variable parameters. First, hydroxyapatite was dissolved in phosphoric acid $\left(37 \% \mathrm{H}_{3} \mathrm{PO}_{4}\right)$ solution at the temperatures $\left[{ }^{\circ} \mathrm{C}\right]$ of $75,80,85,90,95$. The molar ratio of $\mathrm{Ca}_{5}\left(\mathrm{PO}_{4}\right)_{3} \mathrm{OH}$ to $\mathrm{H}_{3} \mathrm{PO}_{4}$ was $1: 47.4$ ( by weight, $8 \mathrm{~g}: 100 \mathrm{~g}$ ). Afterwards, calcium sulphate precipitation from the obtained solution was carried out by sulphuric acid (concentration: $15-60 \%$ $\mathrm{H}_{2} \mathrm{SO}_{4}$ ) addition. The amount of $\mathrm{H}_{2} \mathrm{SO}_{4}$, taken for the precipitation, was equivalent to the amount of calcium introduced with $\mathrm{Ca}_{5}\left(\mathrm{PO}_{4}\right)_{3} \mathrm{OH}$. The introduction of $\mathrm{H}_{2} \mathrm{SO}_{4}$ into the solution, containing $\mathrm{Ca}\left(\mathrm{H}_{2} \mathrm{PO}_{4}\right)_{2}$, resulted in white precipitate formation. The hot precipitate was filtered off immediately. In the obtained phosphoric acid phosphorus and calcium and ions were analyzed (Table 7). The precipitate

Table 5. Parameters of the designed experiments

\begin{tabular}{|l|c|c|c|c|c|}
\hline \multirow{2}{*}{ Parameter } & \multicolumn{3}{c|}{ Coded values } & +1.000 & +1.682 \\
\cline { 2 - 6 } & -1.682 & -1.000 & 0 & 50 & 59 \\
\hline $\mathrm{Z}_{1}\left[\% \mathrm{H}_{3} \mathrm{PO}_{4}\right]$ & 15 & 24 & 37 & 91 & 95 \\
\hline $\mathrm{Z}_{2}$ temperature $\left[{ }^{\circ} \mathrm{C}\right]$ & 75 & 79 & 85 & $1: 14$ & $1: 15$ \\
\hline $\mathrm{Z}_{3} \mathrm{HA}: \mathrm{H}_{3} \mathrm{PO}_{4}$ & $1: 10$ & $1: 11$ & $1: 12,5$ & \\
\hline
\end{tabular}

Table 6. Matrix of the experiment designed

\begin{tabular}{|c|c|c|c|c|c|c|c|}
\hline \multirow{3}{*}{$\frac{\mathrm{N}^{\circ}}{1 .}$} & \multicolumn{7}{|c|}{ Coded values } \\
\hline & \multicolumn{2}{|c|}{$Z_{1}$} & \multicolumn{2}{|c|}{$Z_{2}$} & \multicolumn{2}{|c|}{$Z_{3}$} & \multirow{2}{*}{$\frac{\mathrm{H}_{3} \mathrm{PO}_{4} \text { content in solution, }[\%]}{52.0}$} \\
\hline & +1 & 50 & +1 & 91 & +1 & $1: 14$ & \\
\hline 2. & +1 & 50 & -1 & 79 & +1 & 1:14 & 51.8 \\
\hline 3. & -1 & 24 & +1 & 91 & +1 & $1: 14$ & 28.5 \\
\hline 4. & -1 & 24 & -1 & 79 & +1 & $1: 14$ & 31.9 \\
\hline 5. & +1 & 50 & +1 & 91 & -1 & $1: 11$ & 51.9 \\
\hline 6. & +1 & 50 & -1 & 79 & -1 & $1: 11$ & 51.7 \\
\hline 7. & -1 & 24 & +1 & 91 & -1 & $1: 11$ & 30.4 \\
\hline 8. & -1 & 24 & -1 & 79 & -1 & $1: 11$ & 30.2 \\
\hline 9. & -1.682 & 15 & 0 & 85 & 0 & $1: 12.5$ & 24.2 \\
\hline 10. & +1.682 & 59 & 0 & 85 & 0 & $1: 12.5$ & 37.7 \\
\hline 11. & 0 & 37 & -1.682 & 75 & 0 & $1: 12.5$ & 39.6 \\
\hline 12. & 0 & 37 & +1.682 & 95 & 0 & $1: 12,5$ & 39.9 \\
\hline 13. & 0 & 37 & 0 & 85 & -1.682 & $1: 10$ & 40.1 \\
\hline 14. & 0 & 37 & 0 & 85 & $+1,682$ & $1: 15$ & 39.8 \\
\hline 15. & 0 & 37 & 0 & 85 & 0 & $1: 12.5$ & 39.2 \\
\hline 16. & 0 & 37 & 0 & 85 & 0 & $1: 12.5$ & 39.8 \\
\hline 17. & 0 & 37 & 0 & 85 & 0 & $1: 12.5$ & 39.8 \\
\hline 18. & 0 & 37 & 0 & 85 & 0 & $1: 12.5$ & 39.9 \\
\hline 19. & 0 & 37 & 0 & 85 & 0 & $1: 12.5$ & 40.1 \\
\hline 20. & 0 & 37 & 0 & 85 & 0 & $1: 12.5$ & 40.2 \\
\hline
\end{tabular}


was subjected to X-ray diffraction and for water and phosphorus content analysis.

The data in Table 7 indicate that when the concentration of the sulphuric acid is increasing, introduced for calcium sulphate precipitation, calcium concentration in the obtained phosphoric acid is decreasing, but sulphate-ion concentration is increasing. The X-ray diffraction analysis (Figure 5) of the precipitates obtained in the process of phosphoric acid formation identified gypsum in the precipitate obtained at 85 $-95^{\circ} \mathrm{C}$, while in the precipitate obtained at $75-80^{\circ} \mathrm{C}$, hemihydrate $\mathrm{CaSO}_{4} \cdot 0.5 \mathrm{H}_{2} \mathrm{O}$ was additionally found ${ }^{5}$.
The ciagram of the technological idea of phosphoric acid production from hydroxyapatite obtained by bone wastes incineration is shown in Figure 6. Part of the phosphoric acid, recycled from the filtration section, part of the mixture of phosphoric acid with calcium sulphate, recycled before calcium phosphate was filtered off, and the suspension of hydroxyapatite in water are directed to the reactor equipped with the heating jacket. After the hydroxyapatite was dissolved, sulphuric acid, diluted with the washings from the filtration section, was added. The suspension, containing calcium and phosphoric acid, is filtered off with the use of

Table 7. Result of analysis of phosphoric acid obtained from hydroxyapatite at different temperature

\begin{tabular}{|c|c|c|c|c|c|}
\hline \multirow{2}{*}{$\begin{array}{c}\text { Concentration } \mathrm{H}_{2} \mathrm{SO}_{4} \\
{[\%]}\end{array}$} & \multicolumn{3}{|c|}{ Phosphoric acid analysis, [\%] } & \multicolumn{2}{|c|}{ Precipitate analysis [\%] } \\
\hline & Concentration $\mathrm{H}_{3} \mathrm{PO}_{4}$ & Calcium content & Sulphate content & Water content & $\begin{array}{c}\text { Phosphorus } \\
\text { content }\end{array}$ \\
\hline \multicolumn{6}{|c|}{ Temperature $75^{\circ} \mathrm{C}$} \\
\hline 15 & 29.90 & 0.143 & 0.725 & 34.90 & 4.90 \\
\hline 20 & 31.70 & 0.108 & 0.720 & 33.50 & 4.75 \\
\hline 25 & 32.70 & 0.108 & 0.820 & 36.40 & 3.20 \\
\hline 30 & 33.50 & 0.102 & 0.810 & 34.30 & 5.20 \\
\hline 35 & 34.30 & 0.101 & 0.840 & 32.00 & 5.80 \\
\hline 40 & 38.20 & 0.100 & 0.840 & 22.90 & 4.60 \\
\hline 45 & 38.20 & 0.093 & 0.940 & 22.40 & 3.80 \\
\hline 50 & 38.80 & 0.085 & 0.940 & 22.20 & 2.70 \\
\hline 55 & 39.40 & 0.084 & 0.940 & 21.80 & 1.80 \\
\hline 60 & 41.00 & 0.074 & 0.940 & 20.40 & 1.60 \\
\hline \multicolumn{6}{|c|}{ Temperature $80^{\circ} \mathrm{C}$} \\
\hline 15 & 29.60 & 0.129 & 0.83 & 25.0 & 4.5 \\
\hline 20 & 31.60 & 0.127 & 0.82 & 24.3 & 4.0 \\
\hline 25 & 32.40 & 0.114 & 0.84 & 23.7 & 3.7 \\
\hline 30 & 35.40 & 0.107 & 0.92 & 23.6 & 3.3 \\
\hline 35 & 35.60 & 0.102 & 0.92 & 22.6 & 3.2 \\
\hline 40 & 37.50 & 0.097 & 0.90 & 22.2 & 3.1 \\
\hline 45 & 37.50 & 0.093 & 0.93 & 18.9 & 3.1 \\
\hline 50 & 38.80 & 0.088 & 0.95 & 18.3 & 3.0 \\
\hline 55 & 39.90 & 0.085 & 0.99 & 18.0 & 2.6 \\
\hline 60 & 40.00 & 0.075 & 1.02 & 17.9 & 2.5 \\
\hline \multicolumn{6}{|c|}{ Temperature $85^{\circ} \mathrm{C}$} \\
\hline 15 & 28.1 & 0.143 & 0.80 & 19.9 & 5.1 \\
\hline 20 & 33.1 & 0.131 & 0.82 & 19.8 & 4.0 \\
\hline 25 & 33.5 & 0.120 & 0.88 & 18.5 & 3.7 \\
\hline 30 & 35.9 & 0.119 & 0.97 & 18.0 & 3.5 \\
\hline 35 & 36.5 & 0.094 & 0.99 & 17.5 & 3.2 \\
\hline 40 & 38.5 & 0.090 & 0.99 & 14.6 & 3.0 \\
\hline 45 & 38.5 & 0.084 & 1.00 & 14.0 & 2.9 \\
\hline 50 & 39.1 & 0.079 & 1.03 & 13.6 & 2.5 \\
\hline 55 & 39.2 & 0.075 & 1.02 & 12.9 & 2.5 \\
\hline 60 & 39.9 & 0.073 & 1.03 & 12.2 & 2.3 \\
\hline \multicolumn{6}{|c|}{ Temperature $90^{\circ} \mathrm{C}$} \\
\hline 15 & 28.2 & 0.138 & 0.79 & 20.7 & 5.1 \\
\hline 20 & 33.0 & 0.132 & 0.89 & 19.6 & 4.4 \\
\hline 25 & 34.5 & 0.129 & 0.96 & 18.7 & 3.9 \\
\hline 30 & 35.6 & 0.108 & 0.99 & 14.1 & 3.7 \\
\hline 35 & 37.7 & 0.108 & 0.99 & 14.0 & 3.5 \\
\hline 40 & 37.7 & 0.098 & 1.00 & 13.9 & 3.3 \\
\hline 45 & 40.1 & 0.097 & 1.20 & 13.8 & 2.6 \\
\hline 50 & 40.6 & 0.096 & 1.22 & 7.0 & 2.2 \\
\hline 55 & 40.9 & 0.090 & 1.22 & 7.0 & 2.0 \\
\hline 60 & 41.2 & 0.084 & 1.29 & 6.3 & 1.9 \\
\hline \multicolumn{6}{|c|}{ Temperature $95^{\circ} \mathrm{C}$} \\
\hline 15 & 30.3 & 0.129 & 0.88 & 20.9 & 4.4 \\
\hline 20 & 31.3 & 0.116 & 0.90 & 19.5 & 3.4 \\
\hline 25 & 31.3 & 0.110 & 0.93 & 18.3 & 3.0 \\
\hline 30 & 35.4 & 0.109 & 0.97 & 14.3 & 2.9 \\
\hline 35 & 37.9 & 0.107 & 0.82 & 12.6 & 2.5 \\
\hline 40 & 39.5 & 0.108 & 0.94 & 11.5 & 2.3 \\
\hline 45 & 41.3 & 0.104 & 0.96 & 10.1 & 2.0 \\
\hline 50 & 39.8 & 0.107 & 0.88 & 9.6 & 1.8 \\
\hline 55 & 41.9 & 0.106 & 0.84 & 8.8 & 1.8 \\
\hline 60 & 41.9 & 0.097 & 0.88 & 7.2 & 1.6 \\
\hline
\end{tabular}




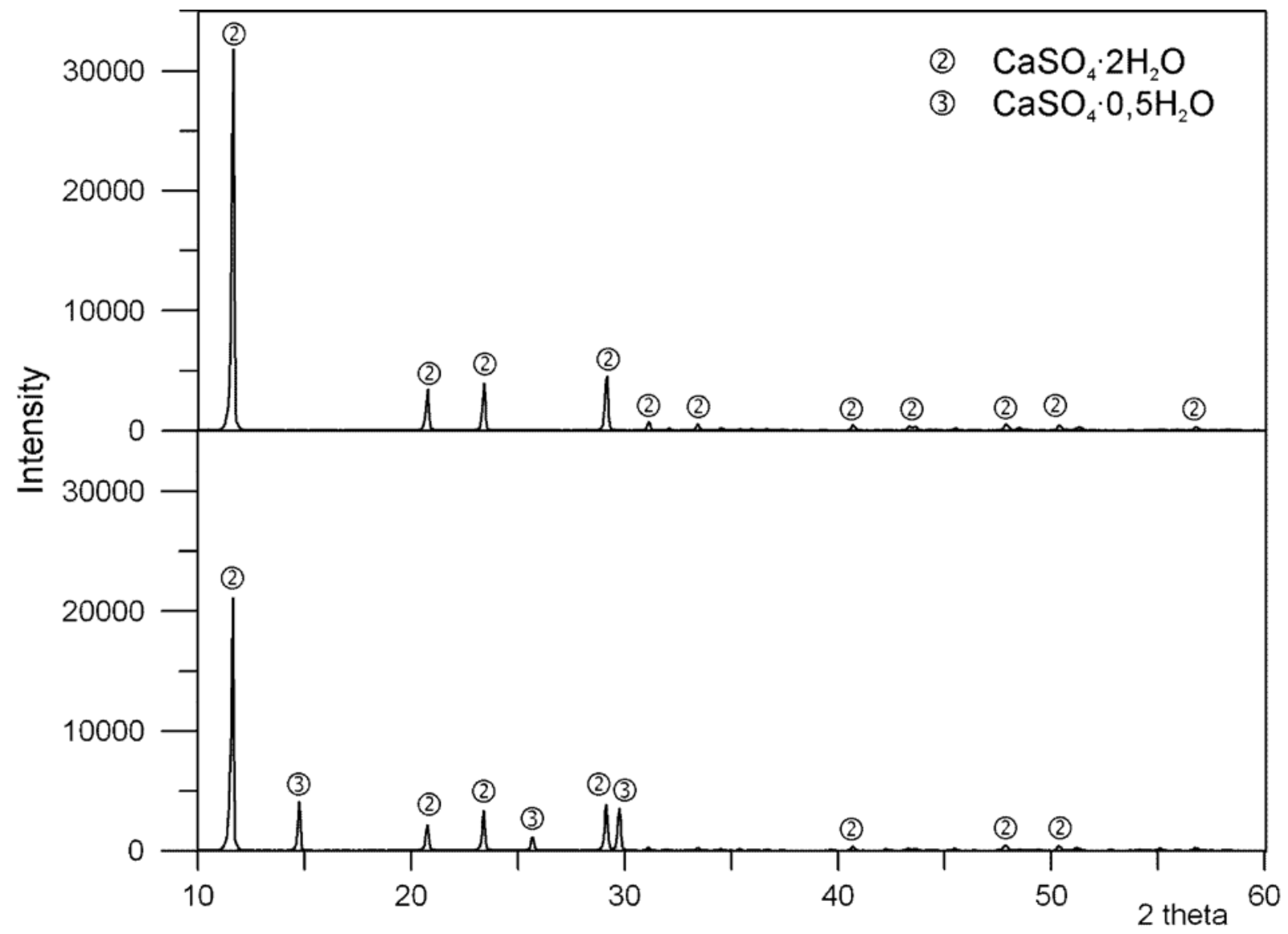

Figure 5. XRD of the precipitate obtained in the process of $\mathrm{H}_{3} \mathrm{PO}_{4}$ formation at temperature of $95(\mathrm{~A})$ and $75^{\circ} \mathrm{C}(\mathrm{B})$. Concentration of sulphuric acid used was $50-60 \% \mathrm{H}_{2} \mathrm{SO}_{4}$

the filter-press. Part of the phosphoric acid obtained has been recycled to the reactor, the rest is directed to the concentrating section. The concentrated phosphoric acid $(75 \%$ $\mathrm{H}_{3} \mathrm{PO}_{4} \sim 54 \mathrm{P}_{2} \mathrm{O}_{5}$ ) can be commercialized or used for the production of phosphoric acid salts by the company. The vapours from the reaction and from the acid concentrating section are condensed. The condensate is used in the filtration section for phosphogypsum washing. The phosphogypsum is temporarily stored and then sold.
In Table 8 the parameters of the phosphoric acid manufacturing from apatite in Wizow Chemical Works plant in comparison to the manufacturing (to be made) from hydroxyapatite, derived from bone wastes has been presented. The assessed cost of the phosphoric acid $\left(100 \% \mathrm{H}_{3} \mathrm{PO}_{4}\right)$ production from hydroxyapatite is $\sim \$ 500 / \mathrm{t}$. The current cost of the commercial food-grade phosphoric acid is on the level of $\$ 1200$. A comparison of these two numbers indicates that the expected profit of phosphoric acid production from the incinerated bone wastes could be high ${ }^{\mathbf{5}}$.

Table 8. Parameters of phosphoric acid technology carried out in $\mathrm{ZCH}$ Wizow plant in comparison to the manufacturing (to be made) from hydroxyapatite, derived from bone wastes [17]

\begin{tabular}{|c|c|c|c|c|}
\hline \multicolumn{4}{|c|}{$\begin{array}{l}\text { Technological parameters of } 1 \mathrm{t} \text { phosphoric acid manufacturing in } \\
\text { ZCH Wizow, Poland }\end{array}$} & \multirow{2}{*}{$\begin{array}{c}\text { Parameters of } 1 \mathrm{t} \text { phosphoric } \\
\text { acid manufacturing (to be } \\
\text { made) from bone- } \\
\text { hydroxyapatite ( } 100 \% \\
\mathrm{H}_{3} \mathrm{PO}_{4} \text { ) }\end{array}$} \\
\hline Parameter & $100 \% \mathrm{P}_{2} \mathrm{O}_{5}$ & $100 \% \mathrm{H}_{3} \mathrm{PO}_{4}$ & $75 \% \mathrm{H}_{3} \mathrm{PO}_{4}$ & \\
\hline Theoretical consumption of $\mathrm{P}_{2} \mathrm{O}_{5}[\mathrm{t}]$ & 1.146 & 0.830 & 0.623 & \\
\hline Theoretical consumption of sulphuric acid $(100 \%)[\mathrm{t}]$ & 2.301 & 1.667 & 1.250 & \\
\hline Practical consumption of $\mathrm{P}_{2} \mathrm{O}_{5}$ from apatite [t] & 1.146 & 0.830 & 0.623 & \\
\hline $\begin{array}{l}\text { Practical consumption of hydroxyapatite, containing } 39 \% \\
\mathrm{P}_{2} \mathrm{O}_{5}[\mathrm{t}]\end{array}$ & & & & 1.334 \\
\hline Practical consumption of sulphuric acid (100\% ) [t] & 2.733 & 1.980 & 1.485 & 1.854 \\
\hline Practical consumption of sulphuric acid (96\%) [t] & 2.847 & 2.063 & 1.547 & 1.932 \\
\hline Consumption of soda [t] & 0.054 & 0.039 & 0.029 & \\
\hline Consumption of deterlon [t] & 0.004 & 0.003 & 0.002 & 0.003 \\
\hline Industrial water $\left[\mathrm{m}^{3}\right]$ & 99 & 72 & 54 & \\
\hline Technological water [t] & & & & 2.203 \\
\hline Electric energy [kWh] & 207 & 150 & 113 & \\
\hline Steam [GJ] & 0.6 & 0.4 & 0.3 & 6.407 \\
\hline Gypsum (20\% water) - waste [t] & 5.494 & 3.980 & 2.985 & 3.292 \\
\hline Amount of liquid acidic wastes $\left[\mathrm{m}^{3}\right]$ & 26 & 19 & 14 & \\
\hline Amount of liquid neutral wastes $\left[\mathrm{m}^{3}\right]$ & 39 & 28 & 21 & \\
\hline
\end{tabular}




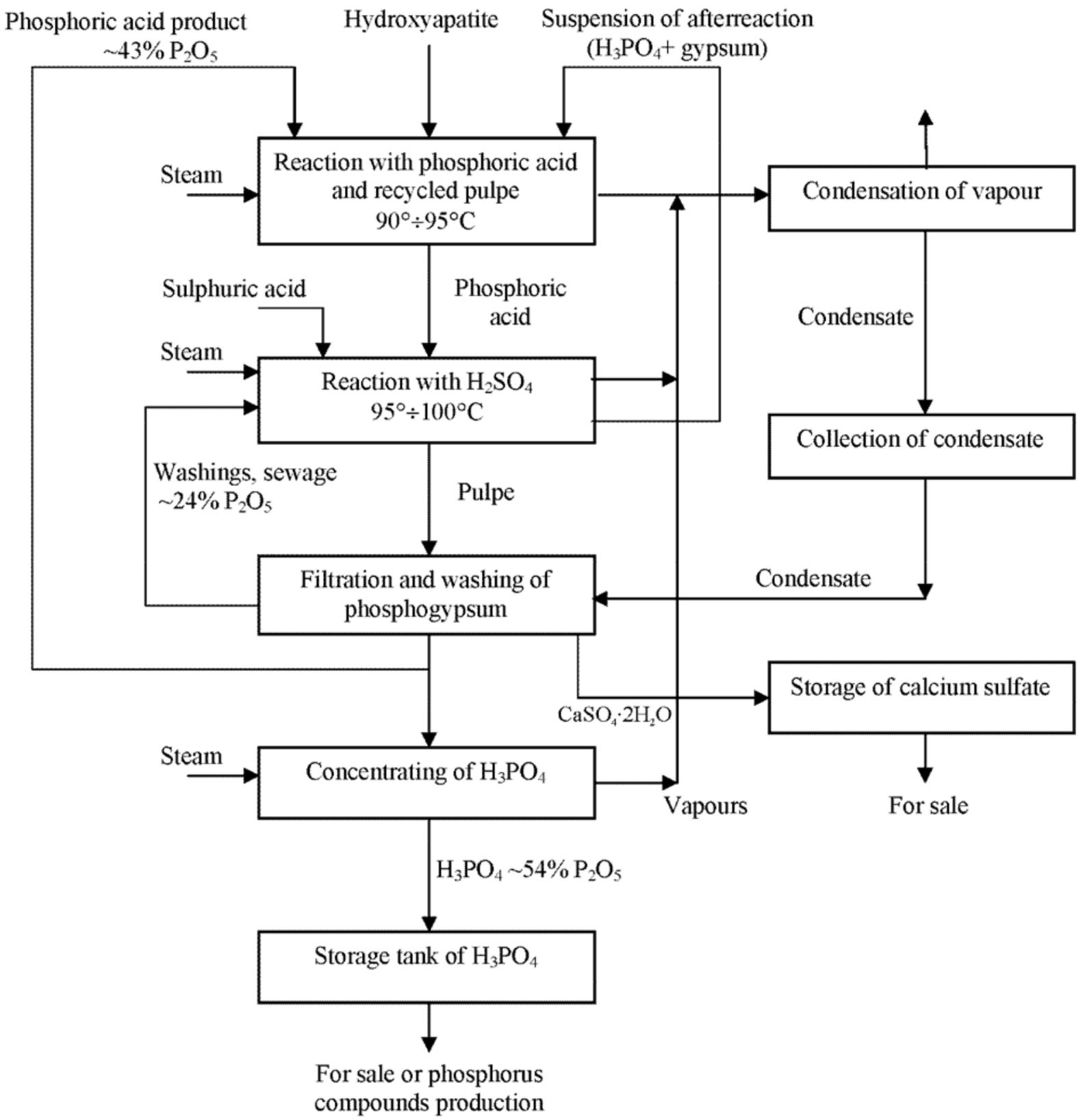

Figure 6. Diagram of the technological idea of phosphoric acid production from hydroxyapatite obtained by bone wastes incineration

\section{CONCLUSION}

The results that led to the elaboration of phosphoric acid production method from the ashes obtained through the incineration of bone wastes from meat industry have been presented. The ash is a valuable alternative source for foodgrade phosphoric acid production. It is characterised by high phosphorus concentration (the level of $16 \% \mathrm{P}$ ) and traces of impurities.

On the basis of the research, carried out on the laboratory scale, the technological parameters of two-stage phosphoric acid processing from hydroxyapatite obtained through the incineration of bone wastes have been evaluated. In the $1^{\text {st }}$ stage hydroxyapatite is dissolved in phosphoric acid to yield mono-calcium phosphate in solution. The overall hydroxyapatite dissolution takes place in phosphoric acid with the $37 \% \mathrm{H}_{3} \mathrm{PO}_{4}$ content. In the $2^{\text {nd }}$ stage calcium phosphate is converted into calcium sulphate using concentrated sulphuric acid.

A preliminary economic analysis of the production of $10000 \mathrm{t} /$ year of food-grade phosphoric acid $\left(100 \% \mathrm{H}_{3} \mathrm{PO}_{4}\right)$ enabled an assessment of the cost of around $\sim \$ 500 /$ t. In comparison to the current cost of the commercial food-grade phosphoric acid $(\sim \$ 1200 / \mathrm{t})$ the expected profit could be high.

\section{LITERATURE CITED}

1. Kowalski, Z. (1998). Czystsza produkcja jako strategia ochrony środowiska naturalnego. Biuletyn nr 3. Kraków, Polska: Komitet Inżynierii Środowiska PAN.

2. Kowalski, Z. \& Kulczycka J. (2004). Cleaner production as a basic element for the sustainable development strategy. P. J. Chem. Technology 6, 4, $35-40$.

3. Steen, I. (1998) Phosphorus availability in the $21^{\text {st }}$ century: Management of non-renewable resources, Phosphorus and Potassium, 217, 25 - 31.

4. Phosphates, August 1997. European Chemical Industry Council and C.E.E.P.

5. Krupa-Żuczek, K. (2007). Receiving phosphoric acid from bone sludge from meat industry. Unpublished doctor`s thesis, Cracow University of Technology, Poland. 
6. Regulation (EC) No 1774/2002 of the European Parliament and of the Council of 3 October 2002 laying down health rules concerning animal by-products not intended for human consumption, Official Journal of the European Communities, No L 273, 10.10.2002.

7. Pezacki, W. (1991). Przetwarzanie surowców rzeźnych. Wplyw na środowisko przyrodnicze. Warszawa, PWN.

8. Konopka, M., Kowalski Z., Fela K., Cholewa J., Bajcer T. \& Klamecki G. (2006). Charakterystyka niskotemperaturowego procesu otrzymywania protein na bazie tkanki mięsno-kostnej z zastosowaniem wybranych enzymów. Recyklace Odpadů X. VŠB Ostrava, Czech Republic, 03.11.2006, $311-316$.

9. Minczewski, J. \& Marczenko, Z. (1965). Chemia analityczna. Warszawa, PWN.

10. Polish Standard. (1988). Chemical fertilizer. Laboratory test of phosphate content. PN-88/C-87015.

11. Wandrasz, A.J. \& Wandrasz, A.Z. (2005). Badanie składu elementarnego $i$ wtaściwości kalorycznych produktów zwierzęcych. Paliwa z odpadów, t.5. Gliwice, Wyd. Helion.

12. Kowalski, Z., Wzorek, Z., Krupa-Żuczek, K. \& Sobczak, A. (2007) Możliwości otrzymywania hydroksyapatytu poprzez kalcynację półproduktów kostnych z przemysłu mięsnego. Inżynieria Stomatologiczna - Biomateriaty, Tom 4, nr 1, 7 - 11.

13. Polish Standard (1997) Fodder. Phosphate of fodder. PN-R-64803.

14. Praca zbiorowa. (1958) Technologia zwiąków fosforowych. Warszawa, PWT.

15. Górecki, H. (1980) Bezodpadowe metody przetwarzania mineralnych surowców fosforowych. Wydawnictwo Politechniki Wrocławskiej, Wrocław.

16. Becker, P. (1983) Phosphates and Phosphoric Acid, Raw materials, Technology and Economics of the Wet process, Marcel Dekker Inc., New York.

17. Unpublished information material of „Wizów” establishment. 